SR 77-20

CRREL

Special Report 77-20

\title{
UNCONFINED COMPRESSION TESTS ON SNOW A Comparative Study
}

A. Kovacs, F. Michitti and J. Kalafut

$$
\text { July } 1977
$$




\begin{tabular}{|c|c|c|}
\hline REPORT DOCUAENTATION P & AGE & $\begin{array}{c}\text { READ INSTRUCTIONS } \\
\text { BEFORE COMPLETING FORM }\end{array}$ \\
\hline $\begin{array}{l}\text { 1. REPORT NUMBER } \\
\text { Special Report } 77-20\end{array}$ & 2. GOVT ACCESSION NO. & 3. RECIPIENT'S CATALOG NUMBER \\
\hline \multirow{2}{*}{\multicolumn{2}{|c|}{$\begin{array}{l}\text { 4. TITLE (and Subtitle) } \\
\text { UNCONFINED COMPRESSION TESTS ON SNOW: } \\
\text { A Comparative Study }\end{array}$}} & 5. TYPE OF REPORT \& PERIOD COVERED \\
\hline & & 6. PERFORMING ORG. REPORT NUMBER \\
\hline \multicolumn{2}{|l|}{$\begin{array}{l}\text { 7. AuTHOR(s) } \\
\text { A. Kovacs, F. Michitti and J. Kalafut }\end{array}$} & 8. CONTRACT OR GRANT NUMBER(B) \\
\hline \multicolumn{2}{|l|}{$\begin{array}{l}\text { 9. PERFORMING ORGANIZATION NAME AND ADDRESS } \\
\text { U.S. Army Cold Regions Research and } \\
\text { Engineering Laboratory } \\
\text { Hanover, New Hampshire } 03755\end{array}$} & $\begin{array}{l}\text { 10. PROGRAM ELEMENT, PROJECT, TASK } \\
\text { AREA \& WORK UNIT NUMBERS } \\
\text { DA Project 1T061101A91A }\end{array}$ \\
\hline \multirow{2}{*}{\multicolumn{2}{|c|}{$\begin{array}{l}\text { 11. CONTROLLING OFFICE NAME AND ADDRESS } \\
\text { U.S. Army Cold Regions Research and } \\
\text { Engineering Laboratory } \\
\text { Hanover, New Hampshire } 03755\end{array}$}} & $\begin{array}{l}\text { 12. REPORT DATE } \\
\text { JUIY } 1977\end{array}$ \\
\hline & & $\begin{array}{l}\text { 13. NUMBER OF PAGES } \\
32 \\
\end{array}$ \\
\hline \multirow{2}{*}{\multicolumn{2}{|c|}{ 14. MONITORING AGENCY NAME a ADDRESS(If different from Controlling Office) }} & $\begin{array}{l}\text { 15. SECURITY CLASS. (of this roport) } \\
\text { Unclassified }\end{array}$ \\
\hline & & $\begin{array}{l}\text { 158. DECLASSIFICATION/DOWNGRADING } \\
\text { SCHEDULE }\end{array}$ \\
\hline
\end{tabular}

Approved for public release; distribution unlimited.

17. DISTRIBUTION STATEMENT (of the abstzact entered in Block 20, if different from Report)

18. SUPPLEMENTARY NOTES

19. KEY WORDS (Continue on reverse side if necessary and identlfy by block number)

Compression

Loads (forces)

Snow

Stresses

20. ABSTRACT (Continue on reverse side if necosaary and identity by block number)

Results of unconfined compression tests performed on snow from Camp Century, Greenland, using a new self-aligning platen system are compared with tests using a more conventional platen system. The average unconfined compressive test strength was $42 \%$ higher for samples tested on the new platen assembly vs the old. Test results indicate that the new platen system provides for better sample alignment and therefore a more uniform load distribution applied to the ends of the sample. The higher strength values obtained with the new platen 
20. Abstract (cont'd)

system are considered more representative of the unconfined compressive strength of the snow tested. 


\section{PREFACE}

This report was prepared by Austin Kovacs, Research Civil Engineer, of the Foundations and Materials Research Branch, Experimental Engineering Division, CRREL, by Frank Michitti, a research civil engineer formerly with CRREL, and by John Kalafut, Electrical Engineer, of the Engineering Services Branch, Technical Services Division, CRREL. Funding was provided by DA Project 1T061101A91A, In-House Laboratory Independent Research. 


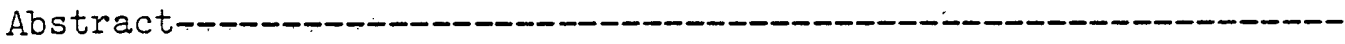

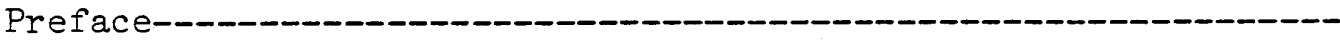

Introduction-

Samples-- - - - -

Test equipment--_-

Test results-_-_-_-_-_-

Discussion--_-

Conclusion--

Literature cited-_-_-_-_-_-_-

\section{ILLUSTRATIONS}

Figure

1. Multi-degree of freedom self-aligning prototype platen assembly used to eliminate misalignment of unconfined compression test specimens--_-

2. The new platen assembly enables self-alignment of unconfined compression test specimens by allowing the platen to shift laterally from $a$ to $b$ and to rotate if necessary--.-.--_-_-

3. Work sheet of $X-Y$ plotter trace of load-time and loaddeflection data from test GR-4--

4. Work sheet of $X-Y$ plotter trace of load-time and loaddeflection data from test GR-5-

5. Work sheet of $X-Y$ plotter trace of load-time and loaddeflection data from test GR-6---

6. Work sheet of $X-Y$ plotter trace of load-time and loaddeflection data from test GR-8-_-

7. Work sheet of $X-Y$ plotter trace of load-time and loaddeflection data from test GR-10-_- 16

8. Work sheet of $X-Y$ plotter trace of load-time and loaddeflection data from test GR-11_-_-_- 17

9. Work sheet of $X-Y$ plotter trace of load-time and loaddeflection data from test GR-13-... 18

10. Work sheet of $X-Y$ plotter trace of load-time and loaddeflection data from test GR-14_- 19

11. Work sheet of $X-Y$ plotter trace of load-time and loaddeflection data from test GR-15-_-_-_-_- 20

12. Work sheet of $X-Y$ plotter trace of load-time and loaddeflection data from test GR-16-_-_-_-_-_ 21

13. Work sheet of $X-Y$ plotter trace of load-time and loaddeflection data from test GR-17-_- 22

14. Work sheet of $X-Y$ plotter trace of load-time and loaddeflection data from test GR-18-_- 
Figure

15. Work sheet of X-Y plotter trace of load-time and loaddeflection data from test GR-21-_._. 24

16. Work sheet of $X-Y$ plotter trace of load-time and loaddeflection data from test GR-22-... 25

17. Work sheet of $X-Y$ plotter trace of load-time and loaddeflection data from test GR-22-_-_- 26

18. Work sheet of $X-Y$ plotter trace of load-time and loaddeflection data from test GR-26_-

TABLES

Table

I. Unconfined compressive strength data on firn from Camp

Century, Greenland-_-_-_-_- 


\section{UNCONFINED COMPRESSION TESTS ON SNOW}

A Comparative Study

Introduction

In 1967 field tests were made (Kovacs et al. 1969) on the unconfined compressive strength of polar snow and ice. The study was performed at Camp Century, Greenland, where samples with densities varying from 0.340 to $0.890 \mathrm{~g} / \mathrm{cm}^{3}$ were tested. In that report, the authors made reference to the significance of the scatter in the test results and put forth "that the primary cause of scatter in the test results data is associated with the singular or combined effects of nonaxially loaded and/or irregularly surfaced specimen ends, and to a lesser degree due to the inherent crystalline or structural flaws." If the scatter were related to nonaxially loaded specimens or to irregularly surfaced specimen ends, it was stated that the more realistic unconfined compressive strengths would be the highest ones. These strengths would have been "obtained from tests in which the samples had most careful preparation and alignment within the testing machine."

Further consideration was given to the alignment problem which resulted in the development of a new platen system designed to ensure nonaxial alignment of unconfined compression test specimens. A description of this platen system and some preliminary results obtained with its use in testing the unconfined compressive strength of freshwater ice are given in a Progress Report "On a Platen Concept for Use when Testing Brittle Materials" (Kovacs 1970). This report indicated that unconfined compression test specimens, no matter how carefully aligned on top of a conventional ball platen, were still misaligned. Therefore the specimens failed at an average 1oad 30\% lower than the apparently more perfectly aligned samples loaded on top of the new self-aligning platen system.

As a result of these findings it was decided to perform additional unconfined compression tests on Greenland snow for the purpose of determining if the use of the new platen system would result in strength values higher than those previously reported. It was anticipated that the new platen system would provide better sample alignment in the testing machine and, therefore, a more uniform stress field across the ends of the sample. If true, the expected higher strengths would support the reasoning advanced by Kovacs et al. (1969) quoted above. This report presents the findings of unconfined compression tests performed at CRREL on $0.600-$ to $0.625-\mathrm{g} / \mathrm{cm}^{3}$ density snow from Camp Century, Greenland - tests which do support the reasoning of Kovacs et al. (1969).

\section{Samples}

Samples of polar snow for this study were obtained from the Inclined Drift at Camp Century, Greenland (Kovacs et al. 1969). Test specimens were selected which had a density between 0.600 and $0.625 \mathrm{~g} / \mathrm{cm}^{3}$. Their average density was $0.612 \mathrm{~g} / \mathrm{cm}^{3}$. This density range was selected for comparison with 15 samples of the same snow tested by Kovacs et al. (1969), which had densities between 0.600 and $0.625 \mathrm{~g} / \mathrm{cm}^{3}$ for an average of 0.617 $\mathrm{g} / \mathrm{cm}^{3}$. 
The samples for this study were prepared in a special jig mounted on a lathe. Each sample was prepared as a smooth-faced right cylinder with ends cut smooth and "flat." The length, diameter and density of each is shown in Table I. The average length and diameter were 20.7 and $7.5 \mathrm{~cm}$, respectively, for a length to diameter ratio of $\approx 2.75$ to 1 . This ratio was selected to minimize the effects of end constraint, which becomes severe below a ratio of 2 to 1.

The samples of Kovacs et al. (1969) were cut to a standard length and planed smooth at the ends on a modified table sander. The ends were then handhoned on fine-grained emery paper to remove minor surface irregularities. Extreme care was also taken to ensure that the side of each sample was perpendicular to the ends. Final samples averaged $7.6 \mathrm{~cm}$ in diameter and $21.0 \mathrm{~cm}$ long, which also gave a length to diameter ratio of $\approx 2.75$ to 1 .

\section{Test Equipment}

The press used in this study was the same one used by Kovacs et al. (1969) at Camp Century. The four-legged frame and cross heads of the press were made with thick steel components prestressed to ensure low compliance under load. A load cell was fixed to the bottom of the upper cross head and a hydraulic ram was built into the base assembly. For the Greenland tests, the ball platen hung from the bottom of the load cell. This rather standard platen configuration did not ensure axial alignment or proper seating of the test specimen. For the comparative test presented in this report, a prototype platen system was connected to the top of the ram piston. It is described by Kovacs (1970) as follows:

As shown in Figure 1, the platen system consists of a number of components. These include the often used platen and platen ball section with the platen ball fixed to the cap of the lower assembly. Highly polished and hardened steel inserts form the underside of the cap and upper face of the base. These inserts have a flatness better than 1/100,000 in. Between these inserts is a loose array of precision balls which give the cap, and therefore the platen, the unique and important feature of $360^{\circ}$ of lateral translation as well as circular rotation on the plane of the base insert. The leaf

springs, fixed to the cap, center the cap over the base. The tension springs between the cap and the platen collar help to keep the platen surface relatively level during raising of the test sample against the upper surface of the testing machine (i.e. the base of the load cell).

Besides providing anchorage for the tension springs, the platen collar supports three linear variable differential transformers (LVDTs). The LVDTs are used to measure sample deflection under load and indirectly provide a means of measuring press speed and time to failure. Signals from the LVDTs and the load cell are recorded at $60 \mathrm{in./sec}$ on a high speed magnetic tape recorder and then played back at $17 / 8 \mathrm{in.} / \mathrm{sec}$ into an $X-Y$ plotter. The latter provides a graphic printout of the complete load vs deflection history of the test specimen up to failure. 
TABLE I

UNCONF INED COMPRESSIVE STRENGTH DATA ON FIRN FROM CAMP CENTURY, GREENIAND

\begin{tabular}{|c|c|c|c|c|c|c|c|c|c|c|c|c|c|c|c|c|c|c|c|}
\hline Sample & $\begin{array}{l}\text { Lengtl } \\
\mathrm{cm}\end{array}$ & in & $\mathrm{cm}^{\mathrm{Di}}$ & in. & $\begin{array}{r}\text { Specific } \\
\text { Gravity } \\
\end{array}$ & $\begin{array}{r}\text { Press } \\
\mathrm{cm} / \mathrm{min}\end{array}$ & $\begin{array}{r}\text { Speed } \\
\mathrm{cm} / \mathrm{min}\end{array}$ & $\begin{array}{c}\text { Time To } \\
\text { Fall. (Sec) }\end{array}$ & $\begin{array}{c}\text { Strain At } \\
\text { Failure }\end{array}$ & $\begin{array}{c}\text { Strain } \\
\text { Rate }\left(\mathrm{Sec}^{-1}\right) \\
\end{array}$ & $\begin{array}{l}\text { Stress At } \\
\mathrm{Kg} / \mathrm{cm}\end{array}$ & $\begin{array}{l}\text { Failure } \\
\text { Psi }\end{array}$ & $\begin{array}{r}\text { Secant } \\
\mathrm{Kg} / \mathrm{cm}^{2} \times 10 \\
\end{array}$ & $\begin{array}{l}\text { Modulus } \\
02 \text { Psi } \times 1\end{array}$ & $\begin{array}{c}\text { Tangent } \\
10^{3} \mathrm{~kg} / \mathrm{cm}^{2} \times 10 \\
\end{array}$ & $\begin{array}{l}\text { lodulus } \\
2 \mathrm{Ps} 1 \times 10 \\
\end{array}$ & $\begin{array}{r}\text { Test } \\
0^{3} \text { Temp } \mathrm{C}^{\mathrm{o}} \\
\end{array}$ & $\begin{array}{r}-25 \mathrm{C} \\
\mathrm{Kg} / \mathrm{cm}^{2} \\
\end{array}$ & $\begin{array}{c}\text { Strength } \\
\text { Psi } \\
\end{array}$ \\
\hline GR-4 & 20.47 & 8.06 & 7.49 & 2.95 & .602 & 6.50 & 2.56 & 0.75 & .00372 & .0050 & 23.7 & 337 & 63.3 & 90 & 221.5 & 315 & -20 & 27.6 & 392 \\
\hline GR-5 & 20.73 & 8.16 & 7.47 & 2.94 & .601 & 9.75 & 3.84 & 0.78 & .00613 & .0078 & 27.4 & 389 & 88.6 & 126 & 163.8 & 233 & $-22^{\circ}$ & 29.7 & 422 \\
\hline GR-6 & 20.70 & 8.15 & 7.44 & 2.93 & .610 & 5.51 & 2.17 & 0.84 & .00372 & .0044 & 30.7 & 437 & 82.3 & $11 \%$ & 184.2 & 262 & -22 & 33.0 & 470 \\
\hline GR-8 & 20.68 & 8.14 & 7.47 & 2.94 & $.610^{\circ}$ & 5.84 & 2.30 & 0.78 & .00391 & .0050 & 28.1 & 399 & 70.3 & 100 & 193.4 & 275 & -22 & 30.4 & 432 \\
\hline CR-10 & 20.78 & 8.18 & 7.47 & 2.94 & .605 & 3.68 & 1.45 & 0.69 & .00205 & .0030 & 27.7 & 394 & 129.4 & 184 & 164.6 & 234 & -22 & 30.0 & 427 \\
\hline CR-11 & 20.78 & 8.18 & 7.49 & 2.95 & .602 & 4.80 & 1.89 & 0.78 & .00301 & .0039 & 28.2 & 403 & 92.8 & 132 & 163.8 & 233 & -22 & 30.7 & $436^{\circ}$ \\
\hline GR-13 & 20.62 & 8.12 & 7.47 & 2.94 & .612 & 6.15 & 2.42 & 0.75 & .00373 & .0050 & 25.0 & 356 & 64.7 & 94 & 178.6 & 254 & -20 & 28.9 & 411 \\
\hline GR-14 & 20.55 & 8.09 & 7.42 & 2.92 & .624 & 5.31 & 2.09 & 0.74 & .00319 & .0043 & 26.6 & 378 & 85.1 & 121 & 175.1 & 249 & -20 & 30.4 & 433 \\
\hline GR-15 & 20.62 & 8.12 & 7.47 & 2.94 & .606 & 4.80 & 1.89 & 0.71 & .00274 & .0039 & 27.2 & 387 & 96.3 & 137 & 158.9 & 226 & -20 & 31.1 & 442 \\
\hline GR-16 & 20.73 & 8.16 & 7.47 & 2.94 & .615 & 4.24 & 1.67 & 0.79 & .00271 & .0034 & 27.8 & 395 & 101.3 & 144 & 182.1 & 259 & -20 & 31.6 & 450 \\
\hline GR-17 & 20.55 & 8.09 & 7.49 & 2.95 & .615 & 4.39 & 1.73 & 0.76 & .00270 & .0036 & 292 & 416 & 110.4 & 157. & 173.0 & 246 & -22 & 31.6 & 449 \\
\hline GR-18 & 20.78 & 8.18 & 7.47 & 2.94 & .615 & 4.22 & 1.66 & 0.71 & .00267 & .0038 & 26.4 & 375 & 99.2 & 141 & 167.4 & 238 & -20 & 30.2 & 430 \\
\hline GR-21 & 20.70 & 8.15 & 7.47 & 2.94 & .622 & 4.09 & 1.61 & 0.70 & .00274 & .0039 & 21.9 & 312 & 80.9 & 115 & 145.6 & 207 & -20 & 25.8 & 367 \\
\hline GR-22 & 20.73 & 8.16 & 7.52 & 2.96 & .614 & 4.78 & 1.88 & 0.80 & .00308 & .0038 & 28.6 & 407 & 92.8 & 132 & 163.1 & 232 & -20 & 32.5 & 462 \\
\hline GR-25 & 20.75 & 8.17 & 2.52 & 2.96 & .617 & 4.22 & 1.66 & 0.69 & .00234 & .0034 & 23.7 & 337 & 69.6 & 99 & 169.5 & 241 & -20 & 27.6 & 392 \\
\hline GR-26 & 20.80 & 8.19 & 2.52 & 2.96 & .614 & 3.91 & 1.54 & 0.76 & .00253 & .0033 & 29.5 & 419 & 117.4 & 167 & 167.4 & 238 & -20 & 33.3 & 474 \\
\hline AVG & 20.68 & 8.14 & 7.47 & 2.94 & .612 & 5.14 & 2.02 & 0.75 & .00318 & .0042 & 27.0 & 384 & 90.0 & 128 & 173.0 & 246 & & 30.2 & 430 \\
\hline
\end{tabular}

$\omega$

\begin{tabular}{|c|c|c|c|c|}
\hline 1 & NA & $\mathrm{NA}$ & $\mathrm{NA}$ & NA \\
\hline 2 & $"$ & " & & \\
\hline 3 & ." & " & " & " \\
\hline 4 & " & " & " & $"$ \\
\hline 5 & $"$ & " & " & " \\
\hline 6 & " & " & $"$ & $"$ \\
\hline 7 & " & " & " & $"$ \\
\hline 8 & " & $"$ & " & $"$ \\
\hline 9 & " & $"$ & " & " \\
\hline 10 & " & ." & " & $"$ \\
\hline 11 & " & " & " & " \\
\hline 12 & " & " & $"$ & $"$ \\
\hline 13 & $"$ & " & " & " \\
\hline 14 & " & " & " & $"$ \\
\hline 15 & " & $"$ & " & $"$ \\
\hline AVG & 20.96 & 8.25 & 7.6 & 3.0 \\
\hline
\end{tabular}

UNCONFINED COMPRESSIVE STRENGTH DATA ON FIRN TESTED AT CAMP CENTURY

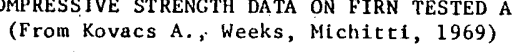

\begin{tabular}{|c|c|c|c|c|c|c|c|}
\hline .608 & 7.49 & 2.95 & 0.39 & $: 00117$ & .0030 & 21.5 & 242 \\
\hline .619 & 10.57 & 4.16 & 0.45 & .00202 & .0045 & 23.0 & 327 \\
\hline .611 & 9.02 & 3.55 & 0.40 & .00168 & .0042 & 19.6 & 279 \\
\hline .617 & 12.37 & 4.87 & 0.30 & .00154 & .0051 & 23.0 & 327 \\
\hline .620 & 16.51 & 6.50 & 0.19 & .00147 & .0077 & 20.0 & 287 \\
\hline .610 & 11.02 & 4.34 & 0.35 & .00175 & .0050 & 17.8 & 253 \\
\hline .623 & 12.80 & 5.04 & 0.40 & .00237 & .0059 & 22.5 & 320 \\
\hline .618 & 10.18 & 4.01 & 0.34 & .00149 & .0044 & 17.8 & 253 \\
\hline .615 & 12.22 & 4.81 & 0.38 & .00242 & .0064 & 20.1 & 286 \\
\hline .621 & 11.02 & 4.34 & 0.40 & :00197 & .0049 & 24.6 & 350 \\
\hline .616 & 9.09 & 3.58 & 0.39 & .00148 & .0038 & 20.2 & 287 \\
\hline .624 & 10.44 & 4.11 & 0.44 & .00219 & .0050 & 22.7 & 323 \\
\hline .622 & 10.16 & 4.00 & 0.45 & .00229 & .0051 & 25.0 & 356 \\
\hline .612 & 11.15 & 4.39 & 0.45 & .00200 & .0044 & 23.0 & 327 \\
\hline .614 & 9.24 & 3.64 & 0.42 & .00175 & .0042 & 21.8 & 309 \\
\hline .617 & 10.90 & 4.29 & 0.38 & .00188 & .0049 & 21.2 & 302 \\
\hline
\end{tabular}

$\begin{array}{rr}145.6 & 207 \\ 113.9 & 162 \\ 116.7 & 166 \\ 149.1 & 21 \\ 137.1 & 195 \\ 102.0 & 14 \\ 94.9 & 135 \\ 119.6 & 17 \\ 83.0 & 118 \\ 125.2 & 178 \\ 136.4 & 194 \\ 103.4 & 147 \\ 109.0 & 155 \\ 118.1 & 168 \\ 124.5 & 17 \\ 118.1 & 168\end{array}$

\begin{tabular}{|c|c|c|}
\hline 177.2 & 252 & -25 \\
\hline 170.2 & 242 & " \\
\hline 173.0 & 246 & $"$ \\
\hline 172.8 & 260 & $"$ \\
\hline 172.3 & 245 & $"$ \\
\hline 174.4 & 248 & $"$ \\
\hline 147.7 & 210 & $"$ \\
\hline 185.6 & 264 & $"$ \\
\hline 138.5 & 197 & $"$ \\
\hline 177.2 & 252 & " \\
\hline 174.4 & 248 & " \\
\hline 156.1 & 222 & $"$ \\
\hline 163.2 & 232 & $"$ \\
\hline 175.1 & 249 & " \\
\hline 185.6 & 264 & $"$ \\
\hline 168.8 & 240 & -25 \\
\hline
\end{tabular}

207
162
166
212
195
145
135
170
118
178
194
147
155
168
177
168


The above platen system can be used as follows. A test specimen is placed upon the platen, the ram is activated and the specimen is lifted upward against the rigid load cell. At contact the specimen automatically seats itself. This is possible because the cap is free to move laterally, allowing the platen to pivot the specimen into proper alignment. (This movement is illustrated in Figure 2.) The above technique is most desired when the test is to be performed at a set press speed. The automatic alignment feature allows the machine to come up to speed prior to specimen contact with the upper bearing surface.

When press speed is not important and lateral translation of the cap is not desired during the test, the test can be performed as follows. The specimen is brought into alignment by applying a very "low" seating load. The cap is then immobilized by seating the locking screws (shown in Figure 1). Loading is then continued.

A second generation platen system has been designed to eliminate the need to stop and lock the cap (Kovacs 1970). In this study the first generation platen assembly was not locked.

Test Results

It has been shown that when unconfined compression tests are performed on snow ice above $-21.4^{\circ} \mathrm{C}$ at a strain rate faster than $0.0035 / \mathrm{s}$, there is no significant change in the failure stress (Carter 1970). Strain rates lower than $0.0035 / \mathrm{s}$ can have a significant effect upon the failure stress (Korzhavin 1962); therefore, to reduce the strain rate effect, for which there is no satisfactory correction, only samples which failed at rates higher than $0.0030 / \mathrm{s}$ were selected for use in this comparative study.

The time to failure and strain at failure for the unconfined compression test specimens used in this study (Table I) averaged $0.75 \mathrm{~s}$ and $0.00318 \mathrm{~s}$, respectively. The average strain rate was $0.0042 / \mathrm{s}$ compared with $0.0049 / \mathrm{s}$ for the samples tested at Camp Century (see Table I). The fact that the average strain rate for this test program and the one made at Camp Century are above $0.0035 / \mathrm{s}$ and in close agreement with one another should eliminate bias in the failure stress due to strain rate effects and should make direct comparison between the tests possible.

The unconfined compressive strengths listed in Table I show that the specimens tested at Camp Century, Greenland, failed at an average unconfined compressive strength $\sigma_{c}$ of $21.2 \mathrm{kgf} / \mathrm{cm}^{2}$ (302 psi) while those tested on the new self-aligning platen system at CRREL failed at $27.0 \mathrm{kgf} / \mathrm{cm}^{2}$ (384 psi), a $27 \%$ higher stress level. However, Table $I$ also shows that the samples tested in Greenland were at $-25^{\circ} \mathrm{C}$ while those tested at CRREL were $3^{\circ}$ to $5^{\circ} \mathrm{C}$ warmer. There are numerous reports (e.g. Carter 1970, Bender 1957, Butkovich 1954, Kovacs 1967, Mellor and Simith 1966, Peyton 1966, Veinberg 1929, Vitman and Shandrikov 1938, Weeks and Assur 1969, and Wolfe and Thieme 1963) which discuss the $\sigma_{c}$ dependence of snow or ice on temperature. Carter (1970), for example, shows that between $-10^{\circ}$ and $-30^{\circ} \mathrm{C}$ the strength 
of snow ice changes at approximately $2.2 \mathrm{kgf} / \mathrm{cm}^{2}{ }^{\circ} \mathrm{C}\left(31 \mathrm{psi} /{ }^{\circ} \mathrm{C}\right)$. This rate of strength increase is high in comparison to those found by most other investigators. The norm is perhaps best expressed.by the $\sigma_{c}$ vs temperature data of Butkovich (1954), Vitman and Shandrikov (1938) and Wolfe and Thieme (1963). Their data show that in the temperature range of $-20^{\circ} \mathrm{C}$ to $-40^{\circ} \mathrm{C}$ the unconfined compressive strength of ice changes at the rate of $\approx 0.75 \mathrm{~kg} / \mathrm{cm}^{2}{ }_{\mathrm{C}}\left(\approx 11 \mathrm{psi} /{ }^{\mathrm{C}} \mathrm{C}\right)$. To conform with the Camp Century test temperature, the $\sigma_{c}$ values obtained at $-20^{\circ}$ and $-22^{\circ} \mathrm{C}$ have been adjusted to $-25^{\circ} \mathrm{C}$ using the above correction. In so doing the average $\sigma_{\mathrm{c}}$ value for the laboratory tests becomes $30.2 \mathrm{~kg} / \mathrm{cm}^{2}$ ( $\left.430 \mathrm{psi}\right)$ and the difference between the average of the lower Camp Century $\sigma_{c}$ values and that of the laboratory $\sigma_{c}$ values increases to $42 \%$.

It was pointed out that the output from the three LVDT's, which recorded sample deflection and the output from the load cell, were recorded on a highspeed magnetic tape recorder. These signal data were then played back at a much slower speed into an X-Y plotter. Load vs deflection, load vs time, and deflection vs time plots could thus be obtained. Work sheets with the load-deflection and load-time curve for each specimen are shown in Figures 3-18. Electrical noise within the CRREL laboratory picked up by the tape recorder caused the saw-tooth microrelief on the curves. Various filtering techniques were tried in an attempt to eliminate the noise and smooth the curves but they were abandoned when it was noted that the data were adversely affected. The curves nevertheless are exceedingly interesting, for they provide a new insight into the stress-strain behavior of firn and, as Kovacs (1970) has shown for ice up to failure, a load history which can only be observed through the use of a high-speed recorder.

Examination of the load-deflection curves (i.e. stress-strain curves) shows that there was very little curvature prior to Hookian behavior and that the load-deflection curves show one or more steps. The strain adjustment events were not the record of LVDT seating. This is clear from the load vs time curves, which show that each step in the load-deflection curve was accompanied by a sudden decrease in load. This would suggest that stress concentrations were being released by some dilatory event, perhaps one associated with the movement of line defects or the formation of microcracks. This phenomenon was observed in the Camp Century test data (see, for example, stress-strain curves $30 \mathrm{~V}-2$ and $30 \mathrm{~V}-3$ of Fig. 10 in Kovacs et al. 1969) but was not referred to in Kovacs et al. (1969) due to an uncertainty of the reality of such a phenomenon. Experiments by Hudson et al. (1971) indicate that dilatory. adjustments also occur in the stress-strain curves of marble, sandstone and concrete tested in unconfined compression.

With some tests the tangent moduli $E_{T}$ increased after dilation (see Fig. 16) while in others there was a decrease (see Fig. 4). However, for the majority of the tests there was no significant change in $E_{T}$ as a result of dilation. This was surprising as it infers that no "hardening or stiffening" nor structural weakening occurred during this stress-strain readjustment.

The tangent and secant moduli for each test are listed in Table I. No temperature adjustment has been made in moduli from the laboratory tests to conform to the temperature of the Camp Century tests. The reason is that 
Nakaya (1959) has shown that between $-10^{\circ}$ and $-30^{\circ} \mathrm{C}$ there is only a $2.0 \%$ change in the dynamic modulus per ${ }^{\circ} \mathrm{C}$. One may assume that the same would be true for the static modulus. Table I shows that the average tangent modulis: obtained from the laboratory tests $\left(17,300 \mathrm{kgf} / \mathrm{cm}^{2}\right.$ or $\left.246,000 \mathrm{psi}\right)$ and from the Camp Century tests $\left(16,880 \mathrm{kgf} / \mathrm{cm}^{2}\right.$ or $240,000 \mathrm{psi}$ ) are nearly the same. The slight difference which does exist is probably related to the method used to analyze the data from Camp Century, i.e. masking dilation steps in the stress-strain curves. Therefore, for all intents and purposes the tangent moduli are within experimental error and show, as expected, that the two studies were performed on firn with the same structural properties.

In a number of tests following the last dilation recorded the load did not immediately drop to zero but held momentarily or even tried to increase. This may be seen in Figures $7,12,15$, and 17.

Discussion

The strength of snow varies not only with its density and structure but also with external conditions which change its internal nature and stress distribution. In this respect snow and ice exhibit a complexity of polyphases which makes determination of their physical and mechanical properties directly related to the external conditions existing at the time of each determination. Although experiments have been performed on snow and ice during which certain external conditions have been held constant (e.g. temperature, strain rate, load rate, stress, specimen size, etc.), the physical nature of the deformation and strength properties of snow is still not clearly understood. Attempts to develop theories related to snow deformation or collapse under load have therefore lacked agreement with fact. This difficulty is related to the physical nature of snow or ice whose strength and structure change directly with external conditions which have not been adequately determined or taken into consideration.

In this comparative study every effort was made to limit the variables known to affect unconfined compression test results. This included the use of snow samples of virtually the same size, shape and density obtained from the same location. The hydraulic testing machine used for the Camp Century tests was also used at CRREL. The strain rate was nearly the same for both studies but most importantly averaged above $0.0035 / \mathrm{s}$, the rate below which the failure strength of ice increases rapidly and above which no apparent increase in failure strength occurs. The temperature was warmer for the CRREL tests but this effect could be corrected for.

Two variables did exist which made the samples tested and the test apparatus used at CRREL different from those used in the Camp Century study. First, while careful sanding and hand honing of specimen ends was performed on each Camp Century specimen to ensure that the ends were flat, parallel, and perpendicular to the sample axis, it must be considered that the samples prepared on the lathe at CRREL were more nearly perfect right cylinders with flatter ends. Secondly, the platen assembly used at CRREL was, of course, significantly different from that used at Camp Century. Determining the exact contribution of these two variables to the net gain in the $\sigma_{C}$ values noted in the CRREL tests is not possible; however, the relative contribution 
is. Kovacs (1970) performed unconfined compression tests on freshwater ice samples of the same size and shape as those used in this study. The samples were made into right cylinders on the same lathe and tested on the same hydraulic press. The significance of these tests is that the samples tested on the new platen assembly failed at an average $30 \%$ higher stress level than similar samples tested on a conventional platen-ball assembly. It may thus be reasoned that of the $42 \%$ increase in the average failure stress of the firn samples tested at CRREL over those tested at Camp Century, $30 \%$ is the result of better alignment on the new platen assembly and $12 \%$ is due to better specimen preparation.

While the noted increase in failure stress is significant and represents the highest $\sigma_{c}$ values obtained to date on $0.60-0.625 \mathrm{~g} / \mathrm{cm}^{3}$ density snow at these strain rates, the scatter in the data has not been reduced. It is speculated that the scatter is not that associated with imperfect sample preparation or imperfect sample alignment but is the result of inherent crystalline or structural flaws.

The load-deflection curves all show that strain dilation accompanied by load reduction occurred during each of the unconfined compression tests made at CRREL. These adjustments characteristically occurred in $8 \mathrm{~ms}$, during which the highest load decrease noted was $208 \mathrm{~kg}$ ( $460 \mathrm{Ib}$ ) and the highest deflection measured was $0.025 \mathrm{~cm}(0.01 \mathrm{in.})$. The cause of this dilation phenomenon may be associated with strain adjustment around internal dislocations or microfractures (Savage and Mohanty 1969) or with initial splitting of the test specimen into a columnar structure prior to failure. Kovacs (1970) has explained the dislocation as follows:

Whatever the cause, it can be postulated that failure may be brought on prematurely by the elastic-response of the testing machine during this strain adjustment. The reasoning here is that during strain-adjustment the machine is suddenly unloaded and elastically tries to return to its fully unloaded state. The sample., in the process of adjusting to receive additional load, is suddenly overloaded by the "onrushing" machine and fails. If this. is. what happened at failure then the test specimens could have sustained even greater loads. At the least it points out the desirability of performing unconfined compression tests with a stiff machine, i.e. one with "little" compliance, to ensure against premature failure (Kovacs 1970).

For a description of stiff testing machines see, for example, Bieniawski (1966, 1967, 1968 and 1969), Hawkes and Mellor (1970), Hudson et al. (1971), and Rummel and Fairhurst (1970).

\section{Conclusion}

The results of this study support the contention of Kovacs et al. (1969) that their unconfined compressive strengths of Camp Century snow and ice may be low due to possible irregularities on the specimen ends and/or nonaxially loaded samples. Either of these conditions would cause a nonuniform stress field to exist across the sample ends and cause samples to fail at a lower stress level than if a uniform stress field existed. The combined effect of preparing cylindrical firn samples on a lathe and testing them on 
a new multi-degree-of-freedom, self-aligning platen assembly at CRREL was a significant increase ( $42 \%$ ) in the average unconfined compressive strength of 0.600 - to $0.625-\mathrm{g} / \mathrm{cm}^{3}$ density snow over that of samples tested at Camp Century, Greenland. These results coupled with those of Kovacs (1970) show the advantage of using a self-aligning platen system to ensure nonaxial loading of unconfined compression test specimens. It is hoped that other investigators will make similar comparative unconfined compression tests to further document the merit of self-aligning platen systems. With guarded optimism the author believes that such tests will show higher strength values consistently obtained with the use of a self-aligning platen assembly.

\section{Literature Cited}

Bender, J.A. (1957) Testing of a compacted snow runway. American Society of Civil Engineers, Journal of the Air Transport Division, Paper 1342.

Bieniawski, Z.T. (1966) Mechanism of rock fracture in compression. South Africa Council for Scientific and Industrial Research, CSIR Report MEG 459.

Bieniawski, Z.T. (1967) Determination of rock properties. South Africa Council for Scientific and Industrial Research, CSIR Report MEG 518.

Bieniawski, Z.T. (1968) The phenomenon of terminal fracture velocity in rock. Rock Mechanics and Engineering Geology, vol. VI, no. 3 .

Bieniawski, Z.T. (1969) Failure of fractured rock. International Journal of Rock Mechanics and Mining Sciences, vol. 6.

Butkovich, T.R. (1954) Ultimate strength of ice. SIPRE Research Report 11, AD 050514.

Carter, D. (1970) Brittle fracture of snow ice. IAHR Symposium, Ice and its Action on Hydraulic Structures, Reykjavik.

Hawkes I. and M. Mellor (1970) Uniaxial testing in rock mechanics laboratories. Engineering Geology, vol. 4 , no. 3.

Hudson, J.A., E.T. Brown and C. Fairhurst (1971) Optimizing the control of rock failure in servo-controlled laboratory tests. Rock Mechanics, vol. 3, no. 4.

Kovacs, A. (1967) Density, temperature and the unconfined compression strength of polar snow. CRREL Special Report 115, AD 660309.

Kovacs, A., W.F. Weeks and F. Michitti (1969) Variation of some mechanical properties of polar snow, Camp Century, Greenland. CRREL Research Report 276, AD 700995.

Kovacs, A. (1970) Progress report on a platen concept for use when testing "brittle" materials. CREEL Technical Note (unpublished).

Mellor, M. and J.H. Smith (1966) Strength studies of snow. CRREL Research Report 168, AD 631717.

Nakaya, U. (1959) Visco-elastic properties of snow and ice in the Greenland Ice Cap. CRREL Research Report 46, AD 226274. 
Peyton, H.R. (1966) Sea ice strength. Geophysical Institute, University of Alaska, Report no. NR307-247/7-6-55.

Rummel F. and C. Fairhurst (1970) Determination of the post-failure behavior of brittle rock using a servo-controlled testing machine. Rock Mechanics, vol. 2 .

Savage, F.C. and B.B. Mohanty (1969) Does creep cause fracture in brittle rocks? Journal of Geophysical Research, vol. 70, no. 17.

Veinberg, B.P. (1929) The influence of temperature on the mechanical strength of river ice. Glavnaia Geofizicheskaia Observatoria, Izvestiia no. 2.

Vitman, F.F. and N.P. Shandrikov (1938) Some investigations of the mechanical strength of ice (in Russian). Trudy Arkticheskogo Instituta 110, Leningrad.

Weeks, W.F. and A. Assur (1969) Fracture of lake and sea ice. CRREI Research Report 269, AD 697750.

Wolfe, L.H. and J.O. Thieme (1963) Physical and thermal properties of frozen soil and ice. Presentation at 30th Annual Fall Meeting of the Society of. Petroleum Engineers. 


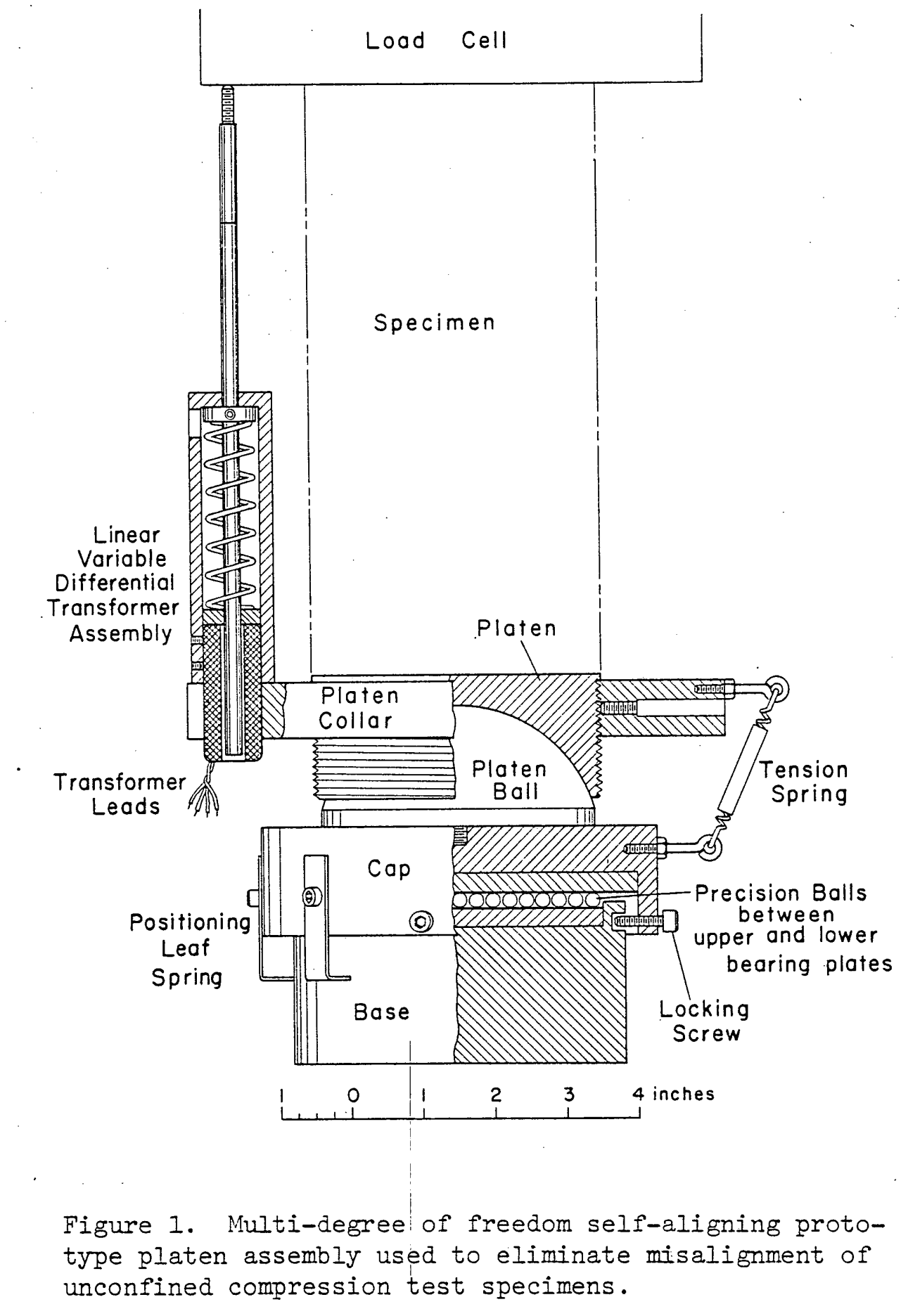




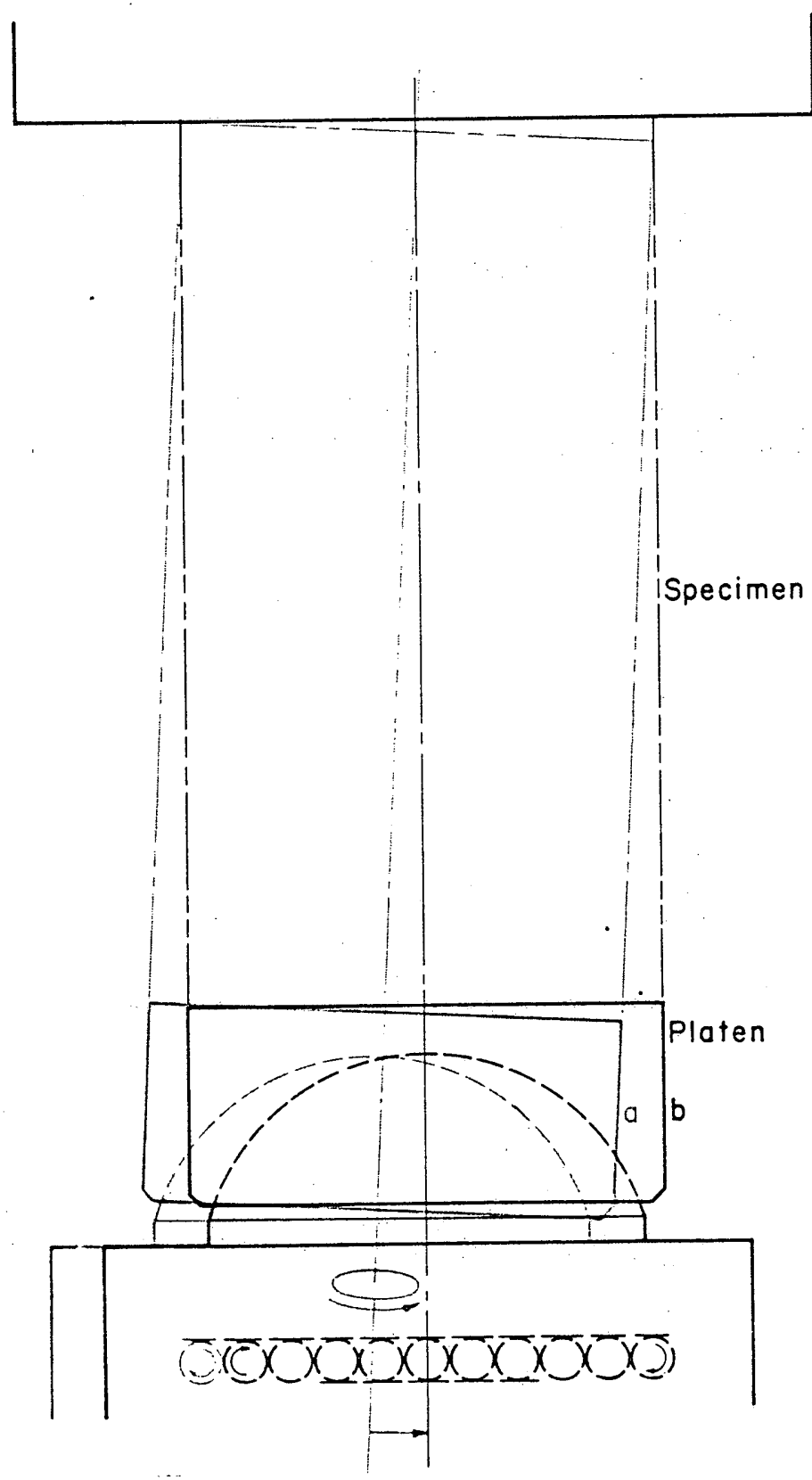

Figure 2. The new platen assembly enables self-alignment of unconfined compression test specimens by allowing the platen to shift laterally from $a$ to $b$ and to rotate if necessary. 


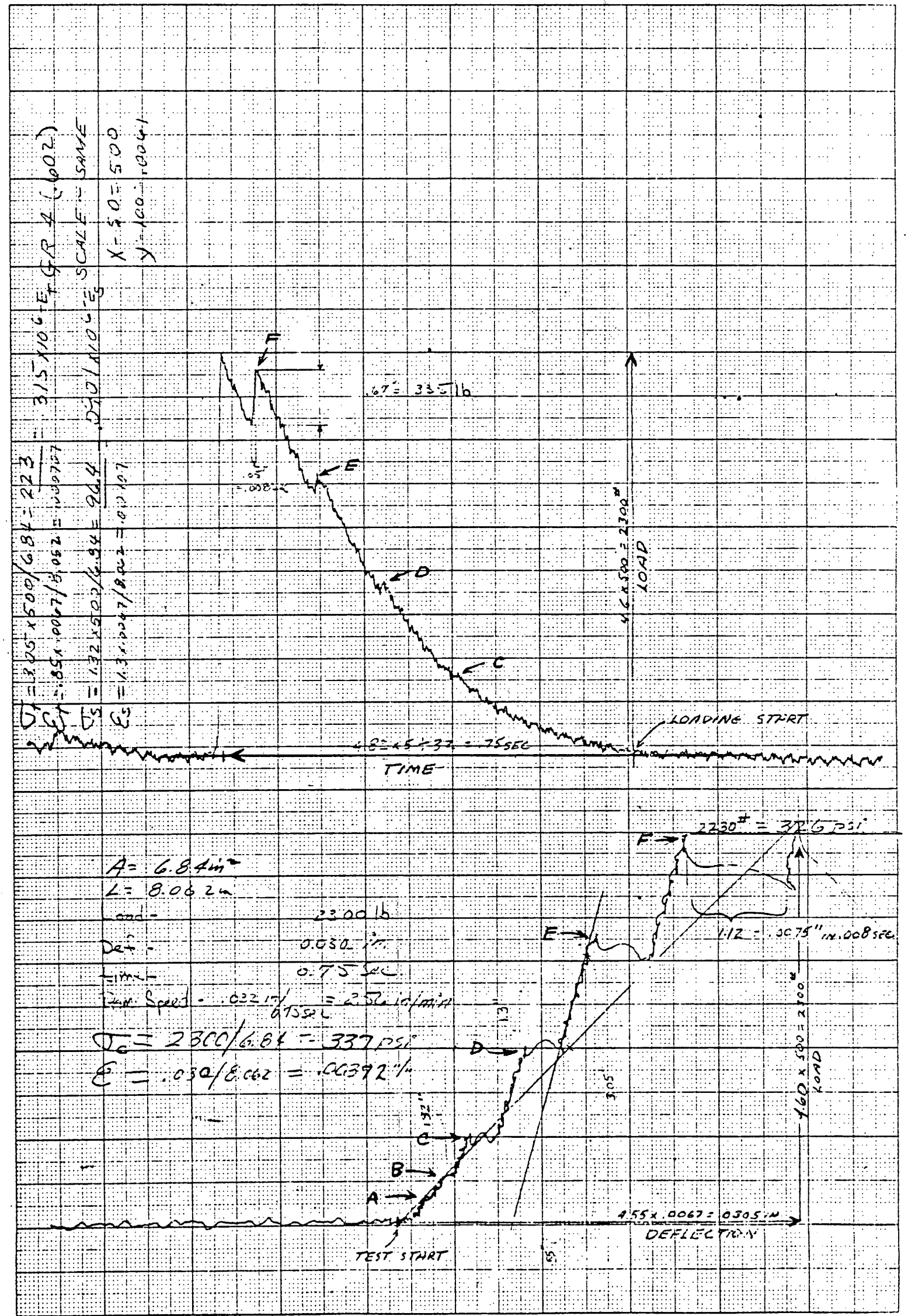

Figure 3. Work sheet of $X-Y$ plotter trace of load-time and load-deflection data from test GR-4. 


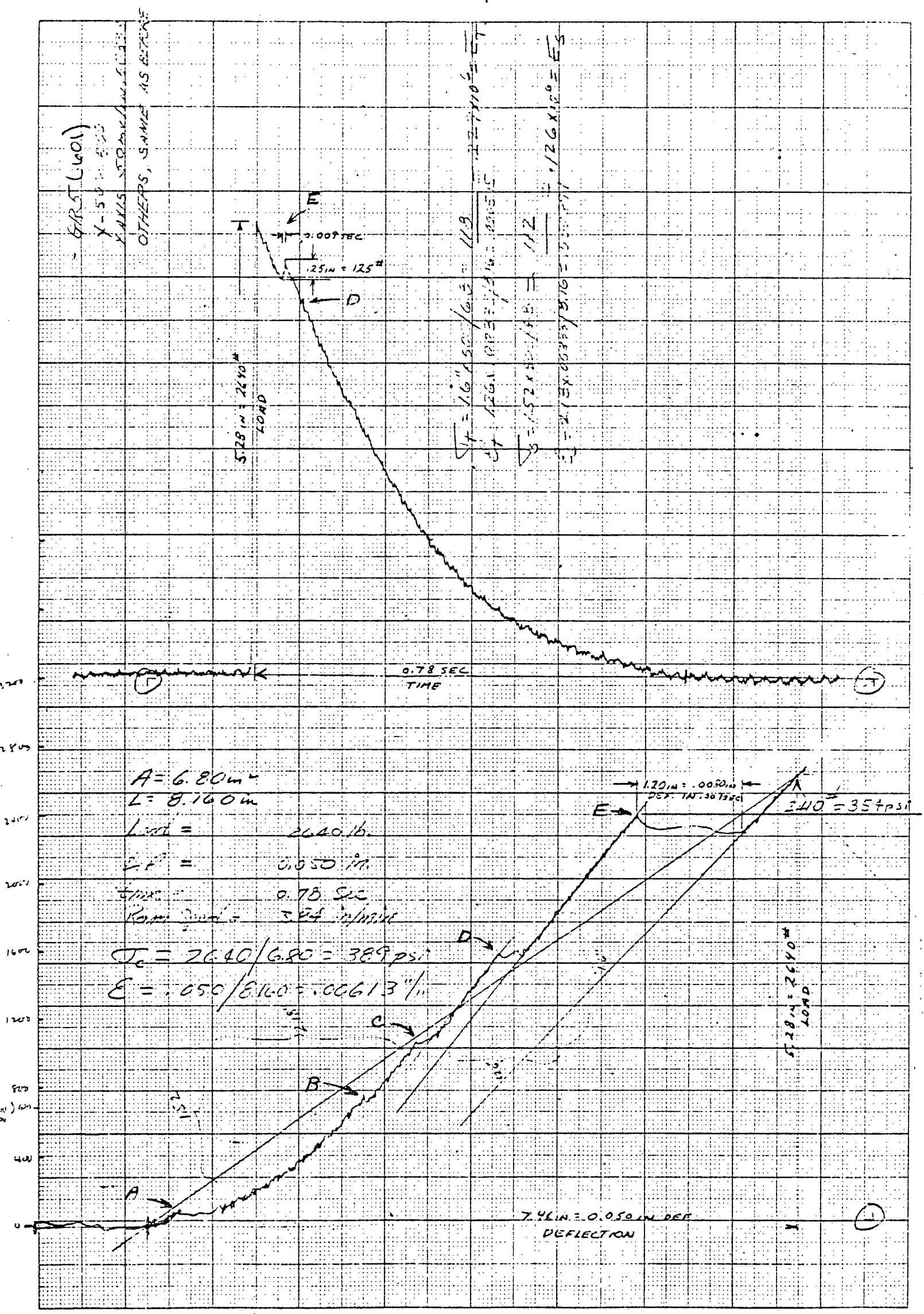

Figure 4. Work sheet of $X-Y$ plotter trace of load-time and load-deflection data from test GR-5. 


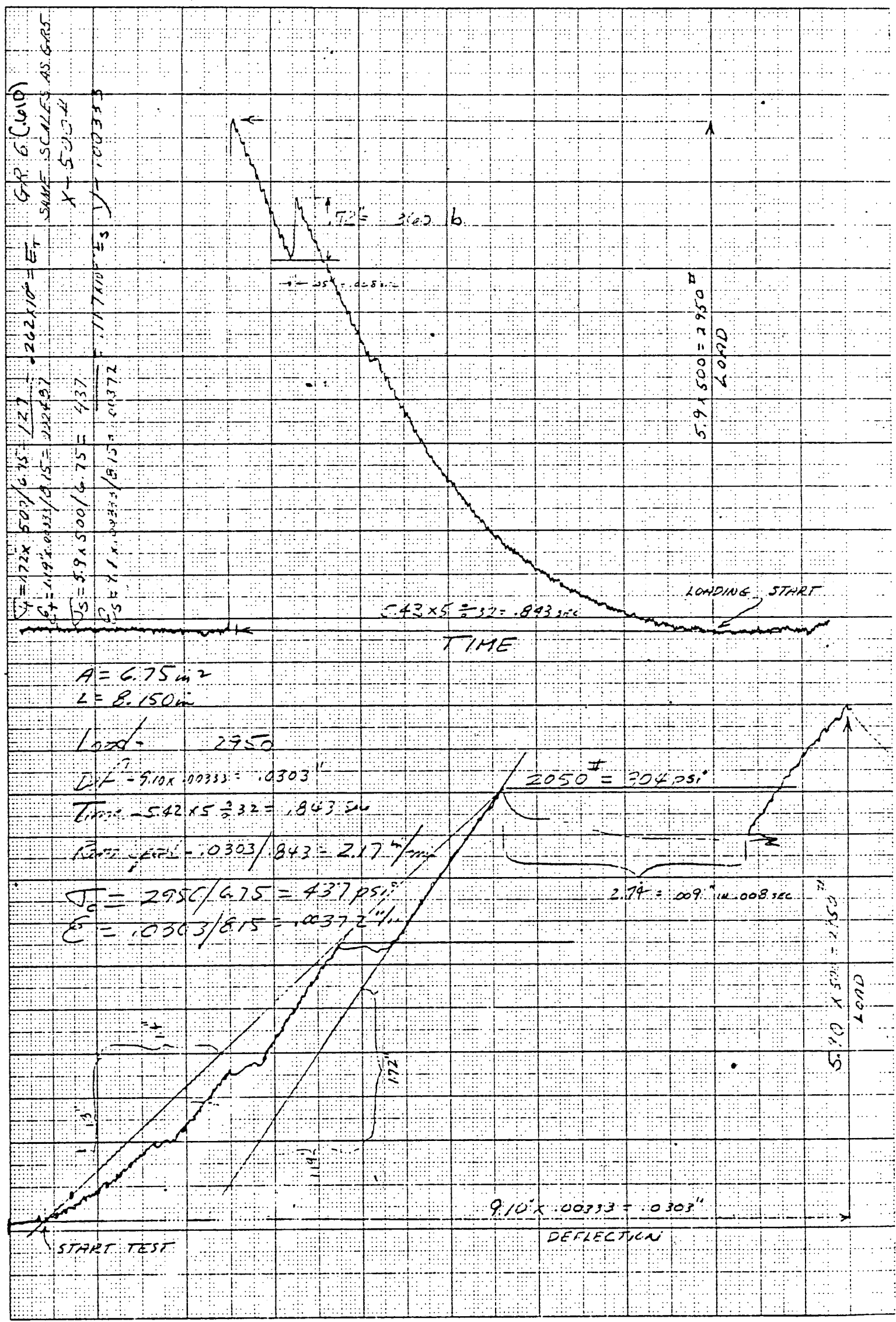

Figure 5. Work sheet of X-Y plotter trace of load-time and load-deflection data from test GR-6. 


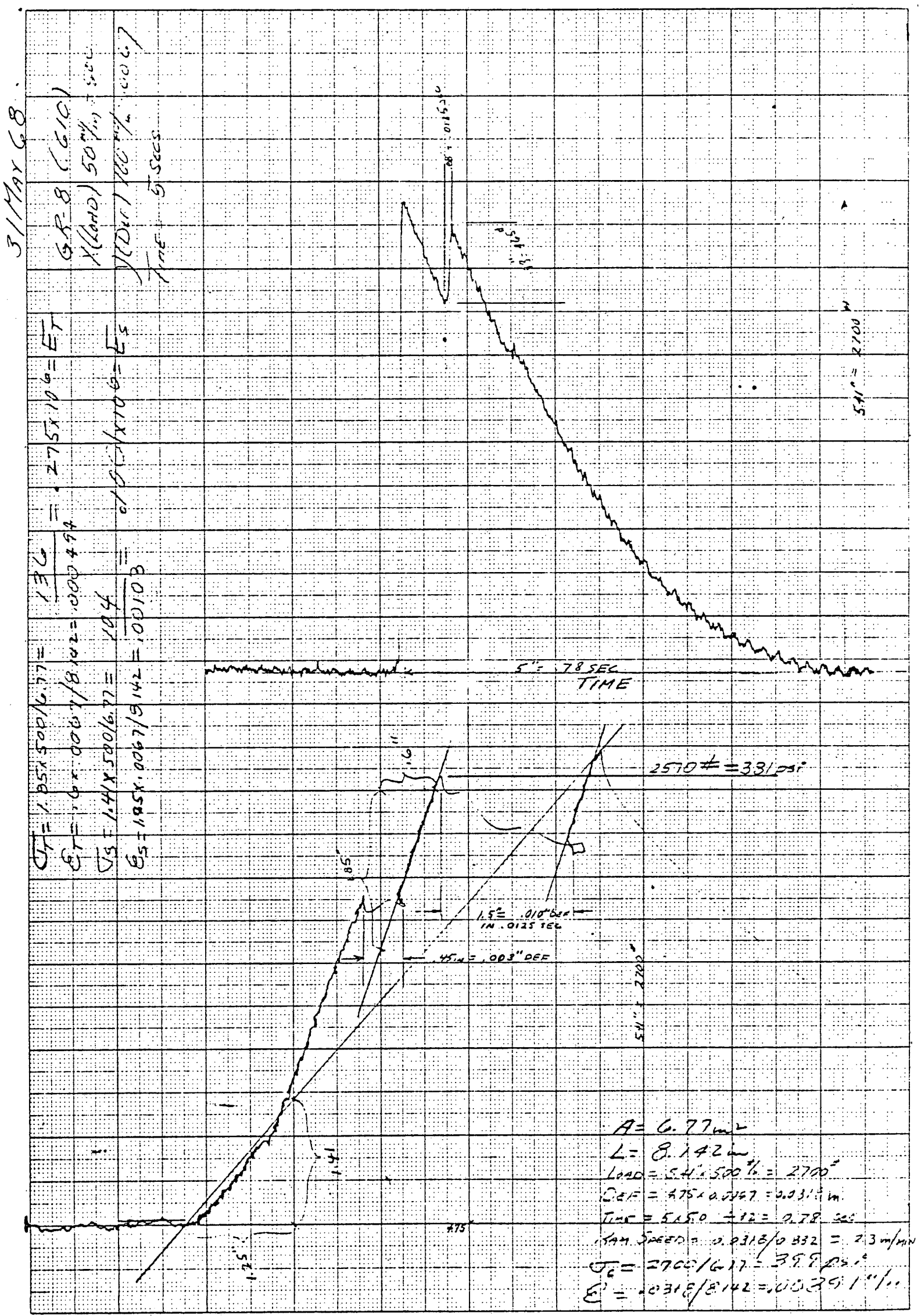

Figure 6. Work sheet of $X-Y$ plotter trace of load-time and load-deflection data from test GR-8. 


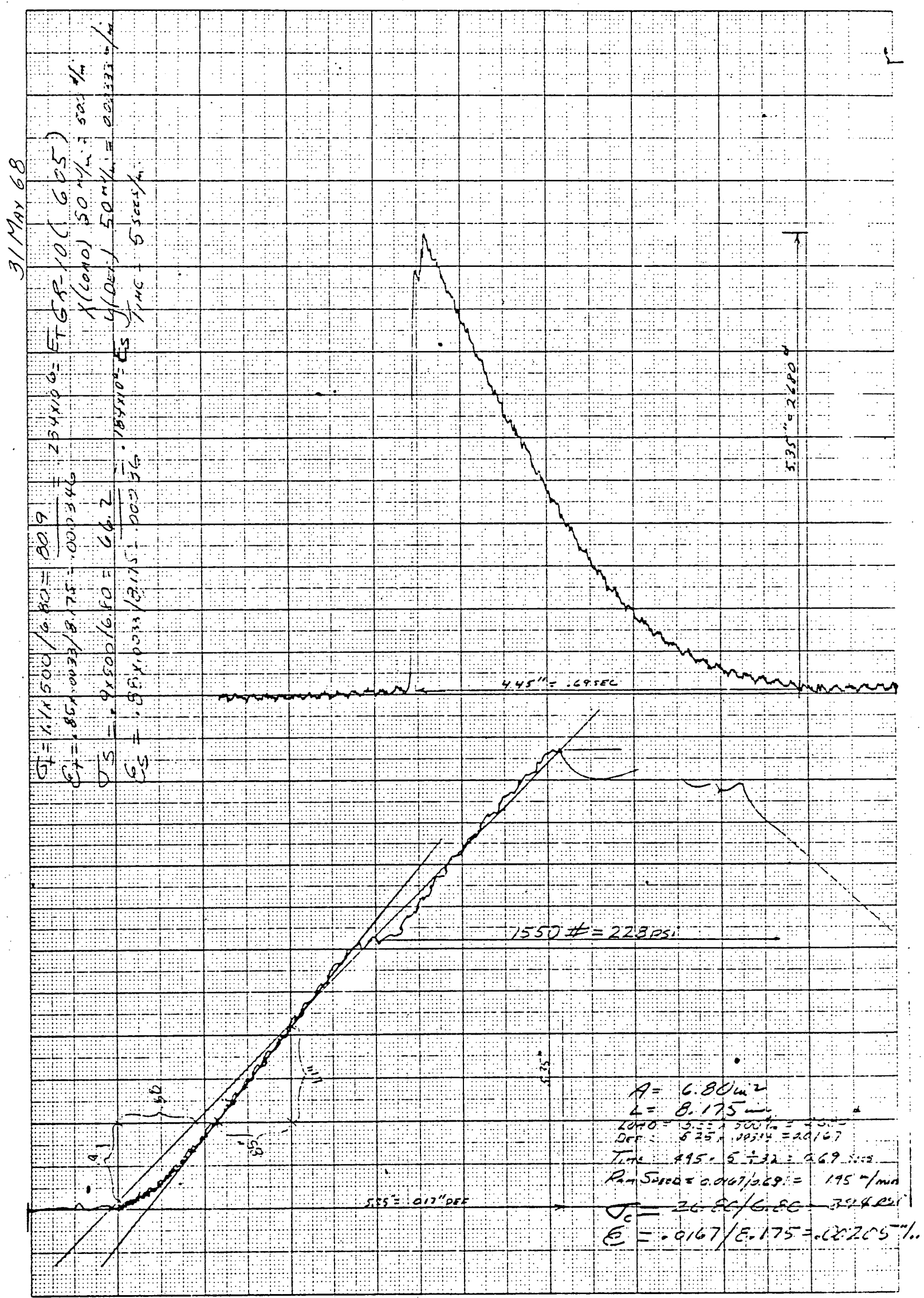

Figure 7. Work sheet of $X-Y$ plotter trace of load-time and load-deflection data from test GR-10. 


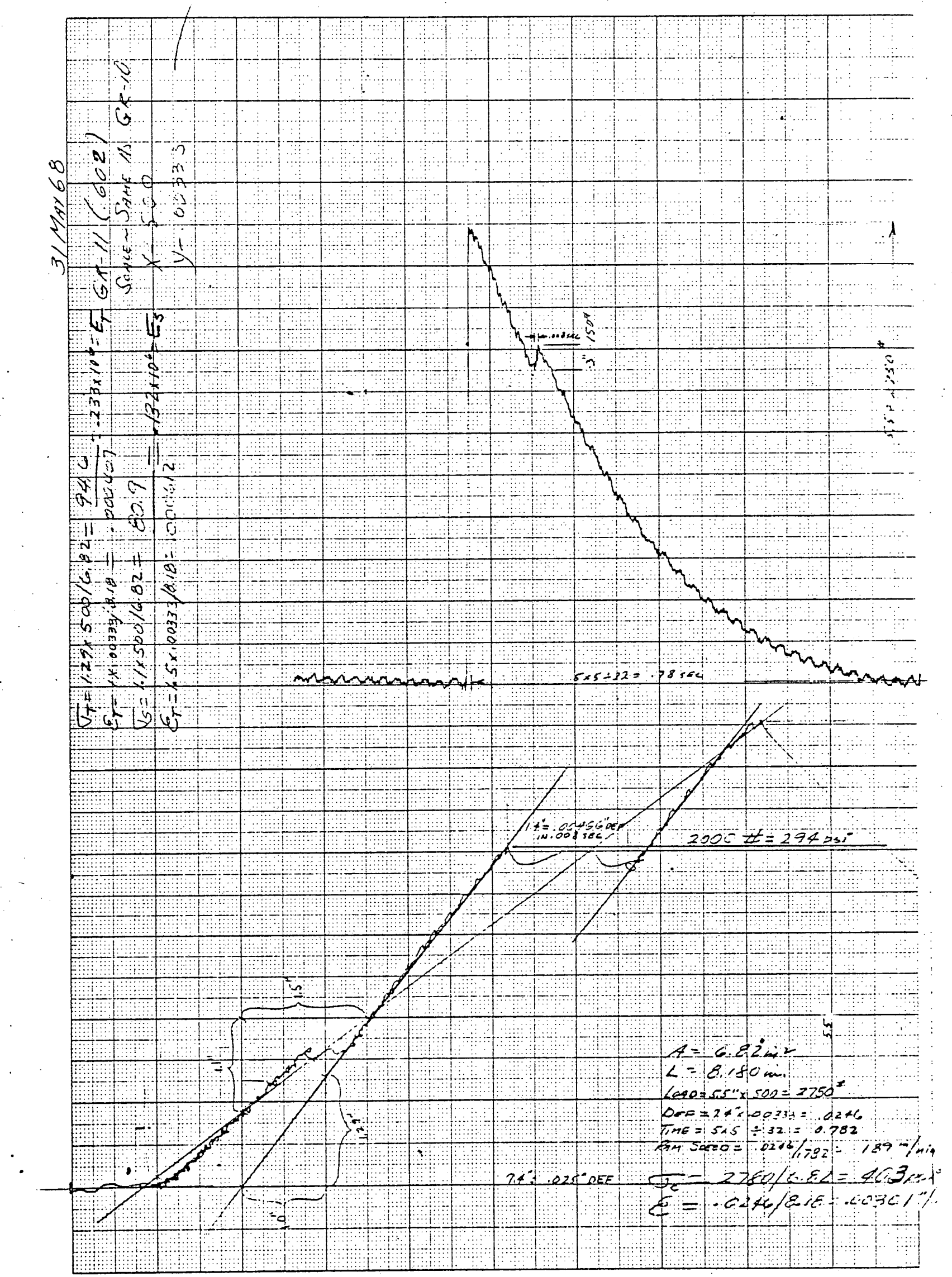

Figure 8. Work sheet of $X-Y$ plotter trace of load-time and load-deflection data from test GR-11. 


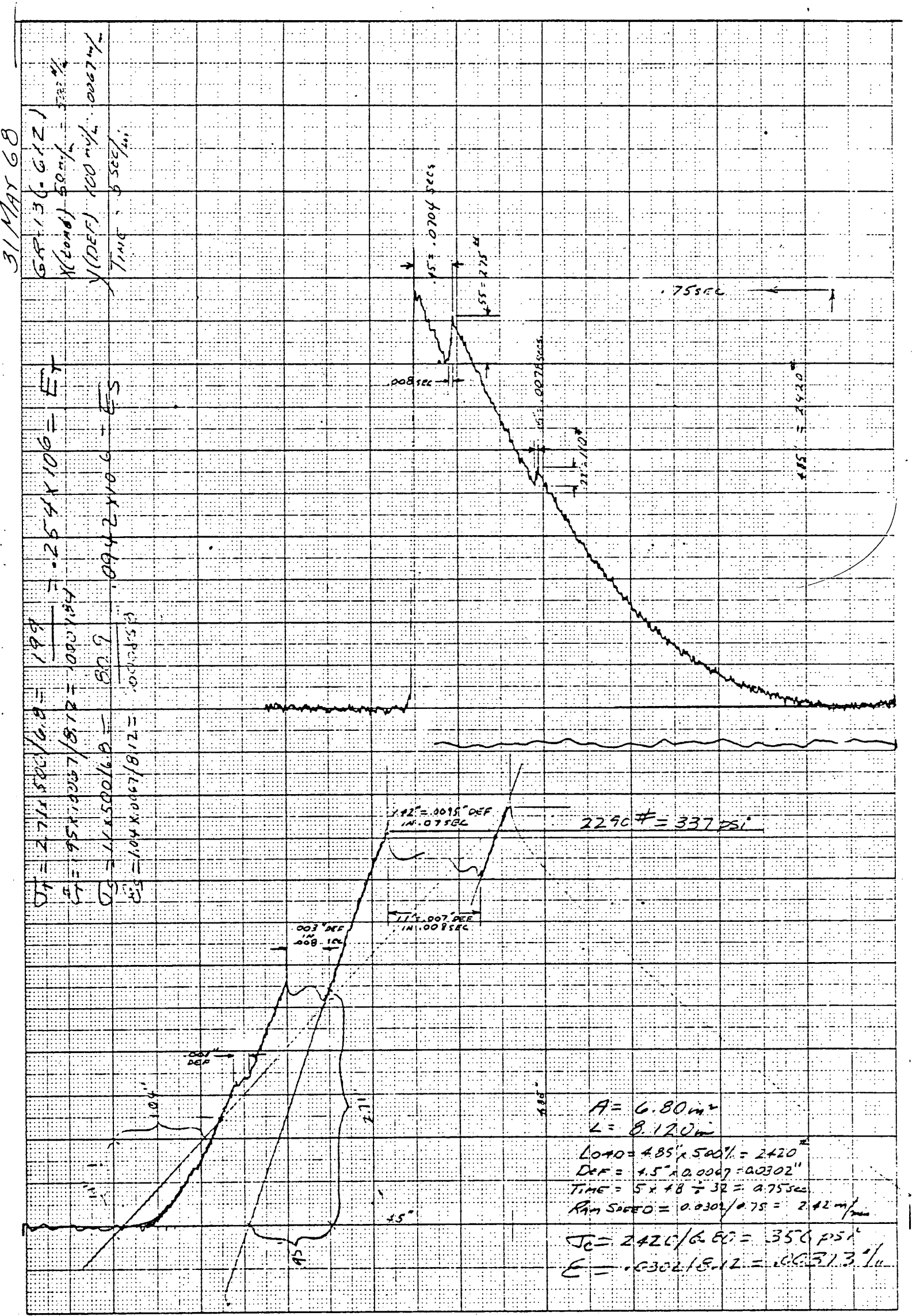

Figure 9. Work sheet of $X-Y$ plotter trace of load-time and load-deflection data from test GR-13. 


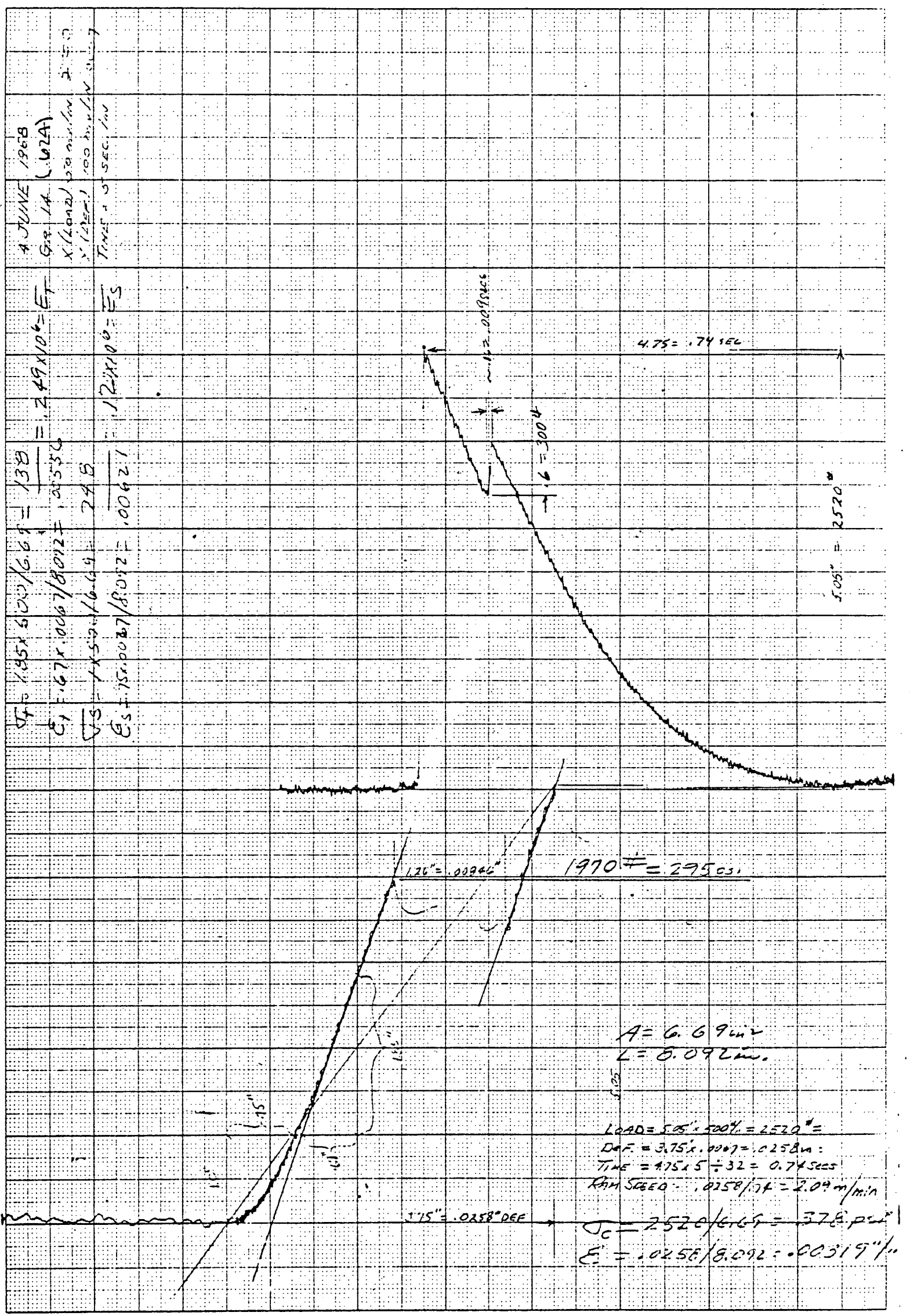

Figure 10. Work sheet of $X-Y$ plotter trace of load-time and load-deflection data from test GR-14. 


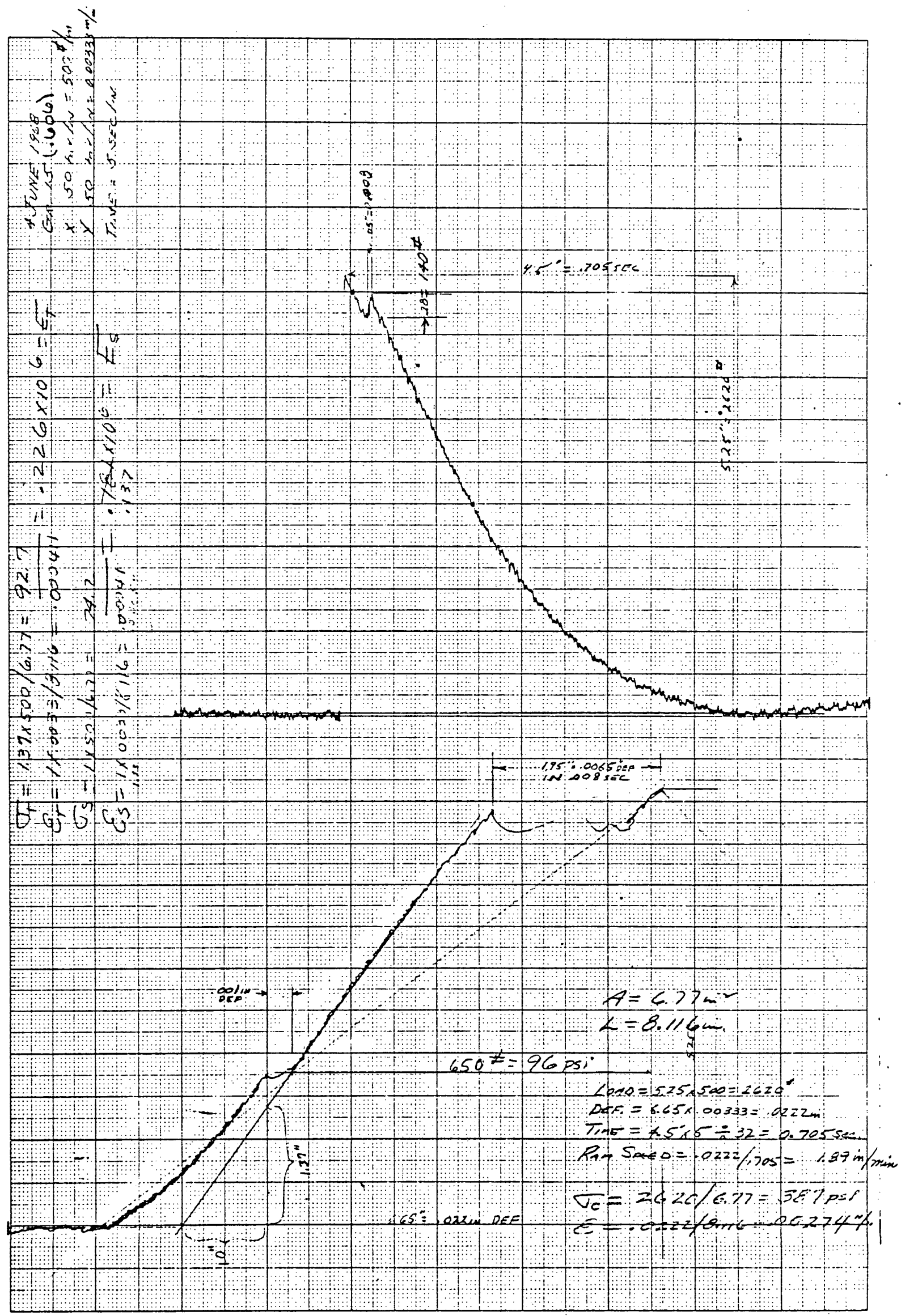

Figure 11. Work sheet of X-Y plotter trace of load-time and load-deflection data from test GR-15. 


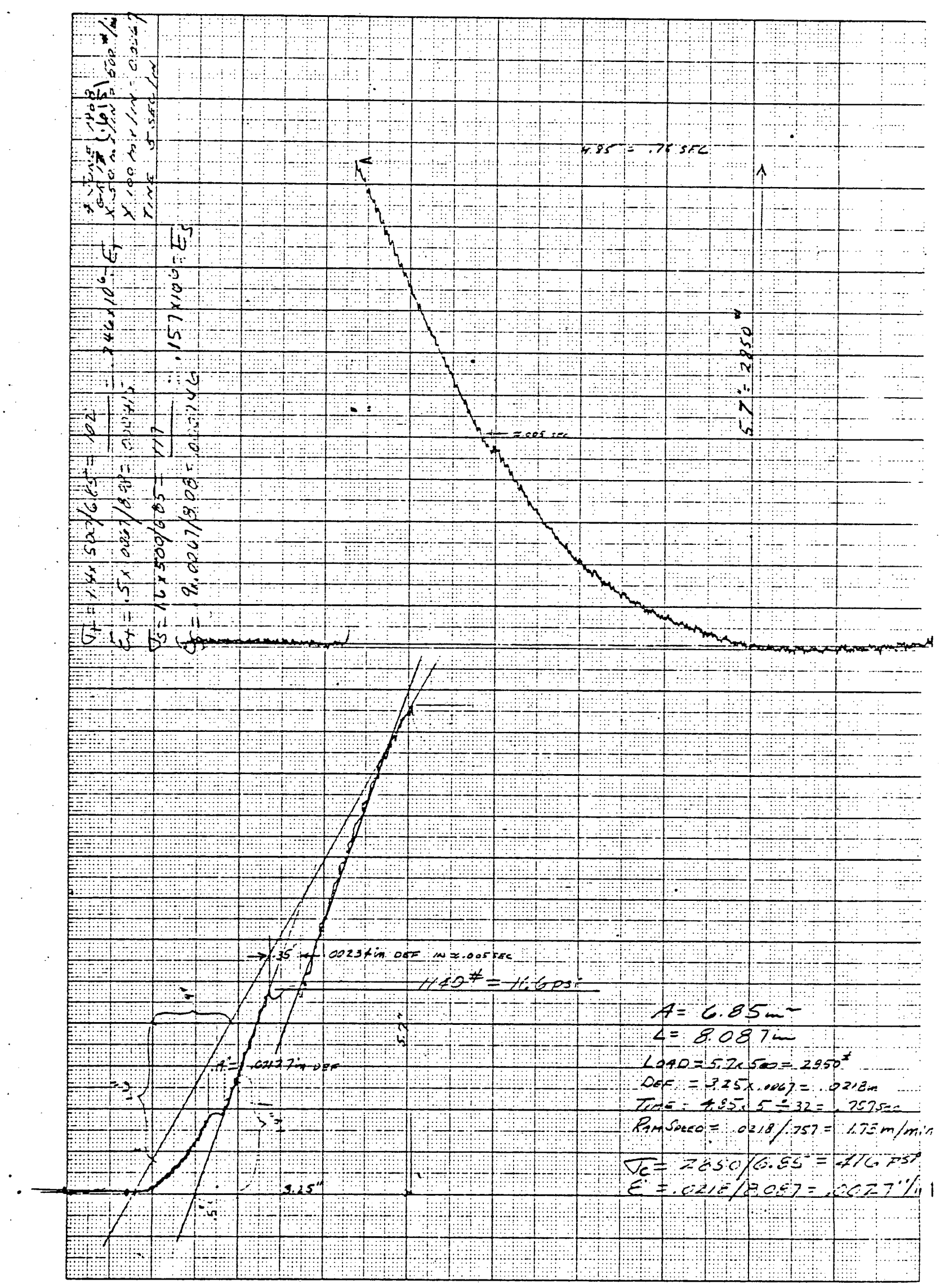

Figure 13. Work sheet of $X-Y$ plotter trace of load-time and load-deflection data from test GR-17. 


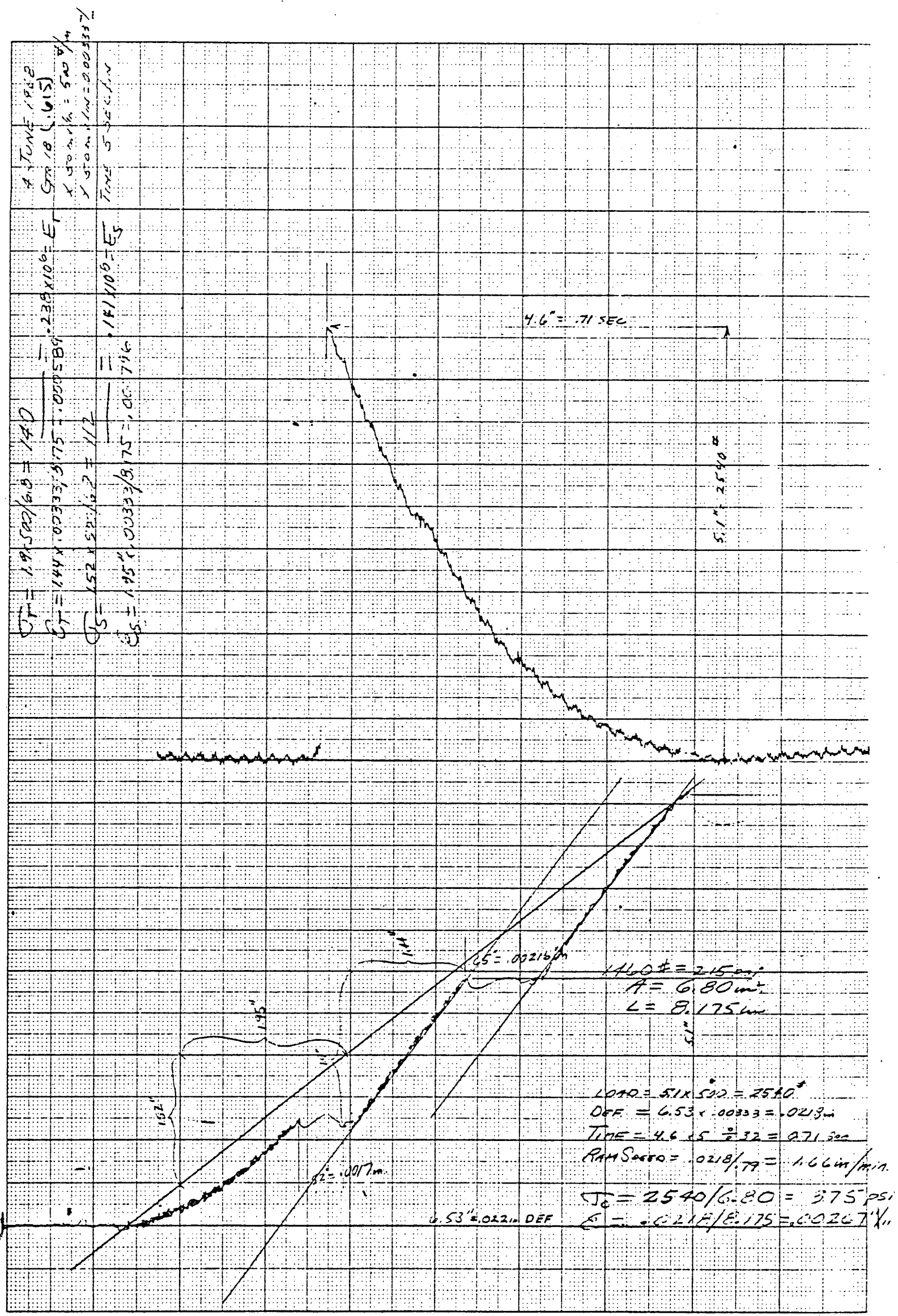

Figure 14. Work sheet of X-Y plotter trace of load-time and load-deflection data from test GR-18. 


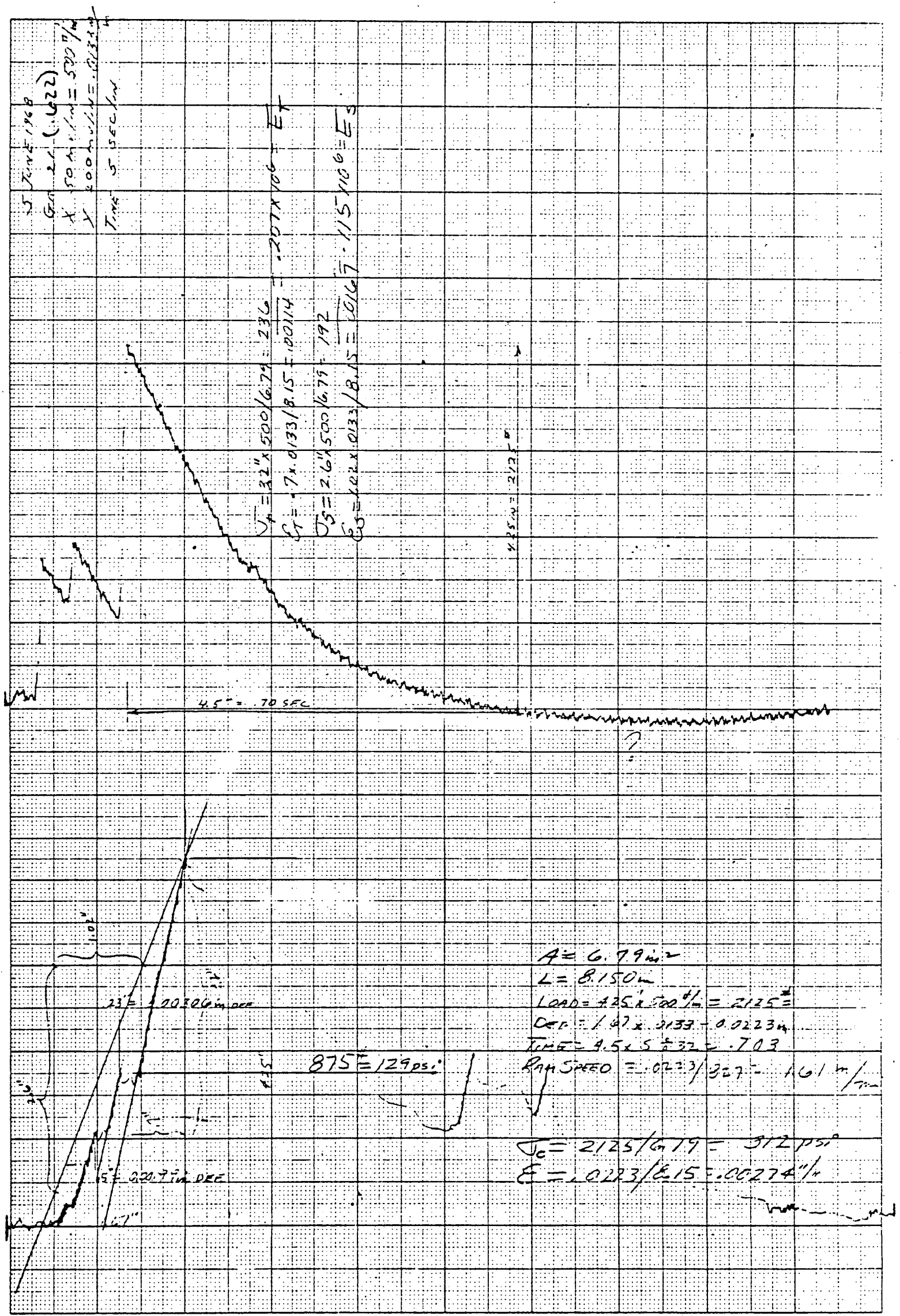

Figure 15. Work sheet of X-Y plotter trace of load-time and load-deflection data from test GR-21. 


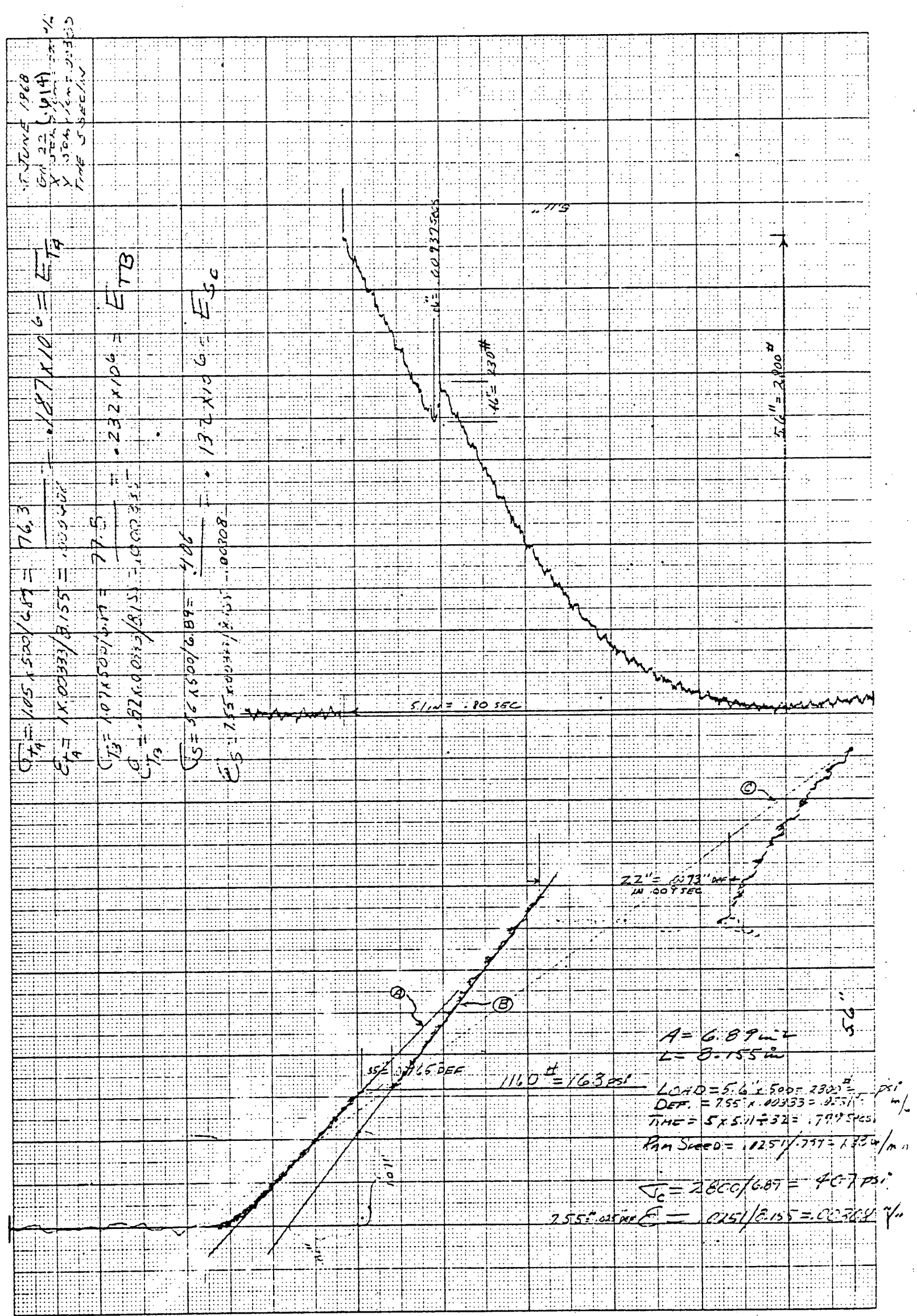

Figure 16. Work sheet of X-Y plotter trace of load-time and load-deflection data from test GR-22. 


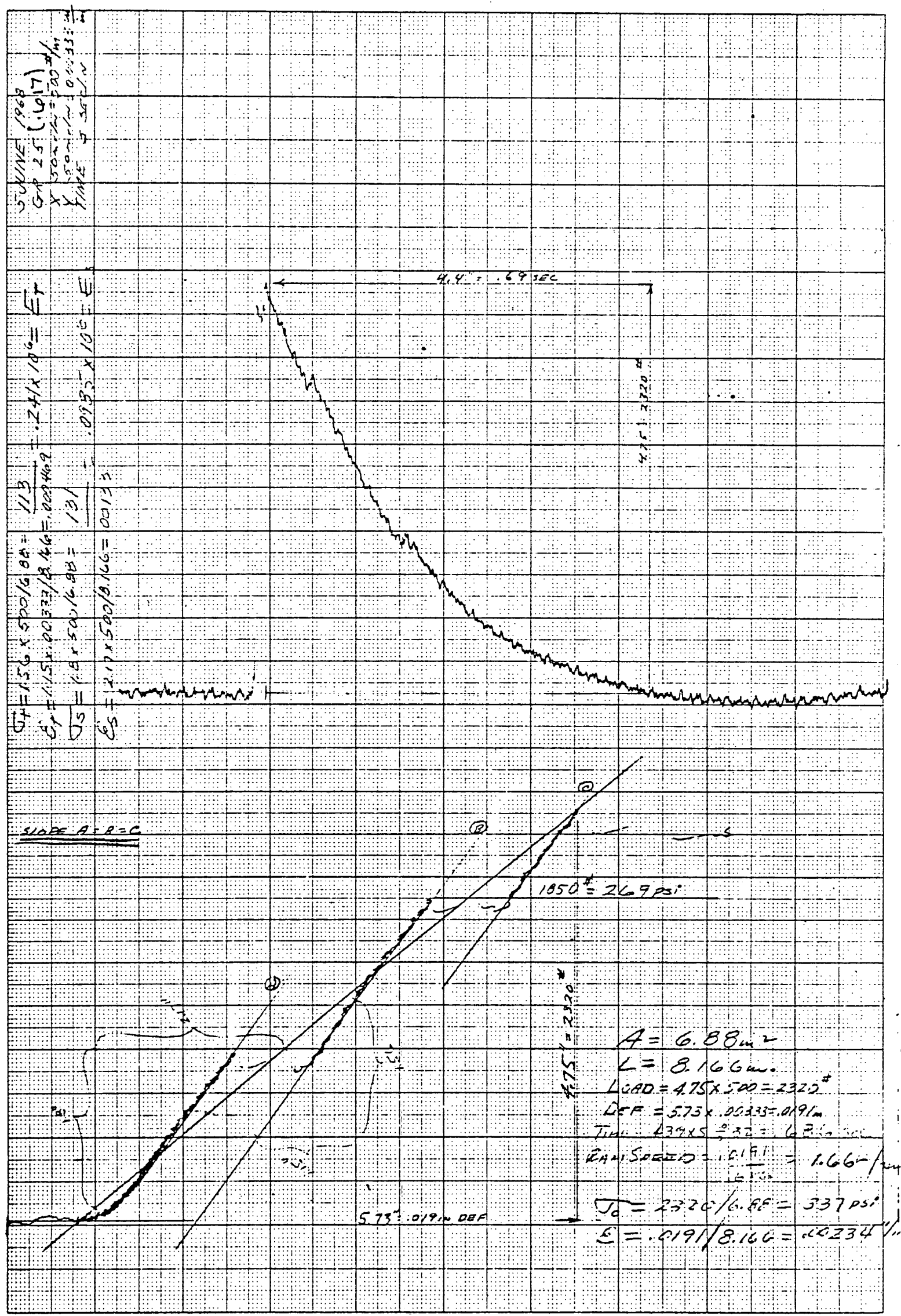

Figure 17. Work sheet of X-Y plotter trace of load-time and load-deflection data from test GR-25. 


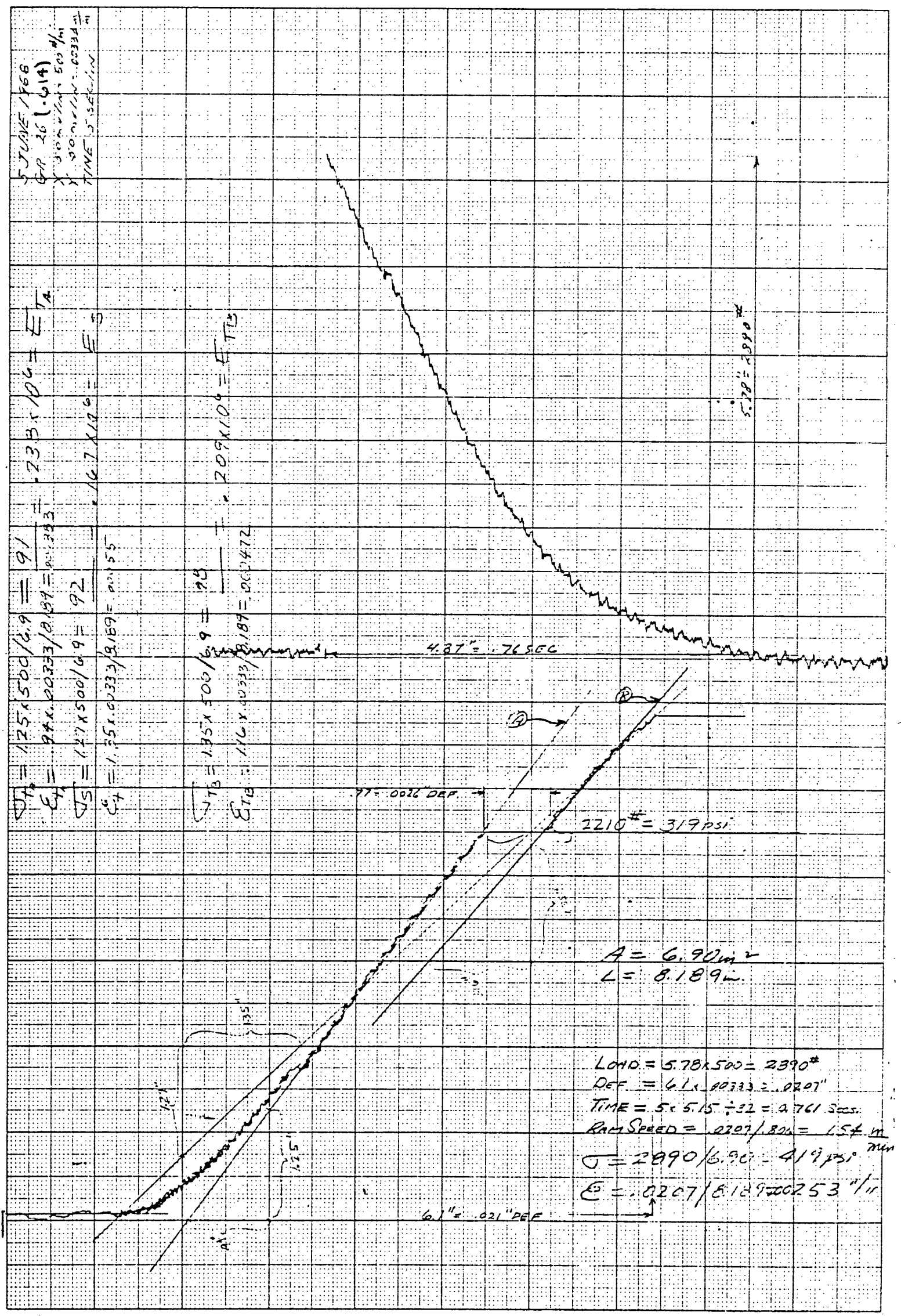

Figure 18. Work sheet of X-Y plotter trace of load-time and load-deflection data from test GR-26. 